\title{
Memories of War and Violence in Anton Pashku's Short Stories
}

\section{Adriana Duka}

\section{Doi:10.5901/jesr.2014.v4n4p17}

Universiteti i Tiranës

\section{Abstract}

Albania is a state where political violence has been present for 45 years, 1945-1990. In our literature after the crash of communism many books were written. They are based on topic of memory of political violence. The Albanian literature includes author and works from Kosovo, Macedonia, Montenegro, which use Albanian language. One of the most important writer of Albanian short stories is Anton Pashku (1937-1995). His short stories aims to discover the relationship between human, war, violence and life. He chose symbolic objects and situations, which describe confrontation of mind with memories. These memories are from real World War II, from occupation of Kosovo by Serbian state, from Albanian dictatorship, but are never named in the short story. The memory of war and violence influence everyday life of character. They live with fear, they are isolated from other people such as real world. They identify themselves with memory, they can not escape from memories. Element such as: smoke, machinery, fire, sound, noise, reveal memories. The short stories of Anton Pashku represent an universal relation of human and memories of violence that are present nowadays. Human and machinery, man and war, man and ethnic identity, human and freedom. The purpose of this presentation is to give aspect of artistic narration of memories.

Keyword: memories, narration, metonymy, grotesque, symbol

\section{Introduction}

Although the war found expression in a number of genres, from histories to memoirs and novels, to the particularly abundant poetry of the war, none of these other fulfill quite the same snapshot function as the short story. Longer prose texts of the war, whereas poetry frequently sought to transcend the specific nature of one war and to appeal to universal human values and experiences - whether these are patriotism and sacrifice, or, in Wilfred Owen's famous words, 'the Pity of War'. Most war novels and memoirs of the inter-war period offer an depth view of the war's experience from the perspective of only one of its protagonist - often the archetypal junior officer (anti-) hero- and the canonized poetry of the war provides short commemorative text useful for purpose of remembrance or anti-war protest. (Ann-Marie Einhause, The Short Story and the First World War. 2013 F. 3-4)

In Albanian literature, the topic of war has been present in hundred short stories written after War Word II, this theme was so dominant that it made them schematic. In general the model of this kind of short story, glorified the National War for Liberation, made by Albanians. The social context was "white and black"; the enemies against the patriot, the evil and the good; the invaders and the heroes. The events in this short stories developed characters who served the society, the person existed only as a hero, often a hero that dies in war. The main idea was the triumph of the positive hero that died for the Albanian country. All this was written under the influence of realism socialism method and under censorship.

On the other hand, a writer far away from templates, with an original style, made the topic of memories of war, part of his best short stories. Anton Pashku was not concentrated on the hero but in the loneliness of character, in his doubt, in his negation, in his absurd and paradox of life. The point of view in narration of Anton Pashku tend to be universal and not national or pathetic. He does not give a name to the characters, does not describe them or set in a real social context. The character may be anyone, everywhere, as time as the war, the violence and totalitarian system cause the same effect.

In Anton Pashku's short stories the topic of war and the consequences are constructed and developed in three levels: the fear, the terror and the salvation.

\section{Metonymy of Fear}

The first form of violence against the individuality in Pashku's short stories is fear. The fear does not start in the beginning of the story, it has been present in life of the main character for a long time, as an anxious state and does not end with the closure of the story. All this is structured with the figure of metonymy. In the short story "Xixëllonjat" , two young people, in a nightmare of war discuss for their fears. 
The fear of the girl has begun in the past of her life, in a retrospect narration come out as a fear by mice, an absurd fear, that is created the disgusting taste when someone just mentions, the mice. The fear of the boy, began in the confrontation with the soldiers, enemies and the war. Both of them have another fear, which is their future. They cannot imagine what will be happening in times of peace. They only hope, although with fear.

The fear has not any face shape, it has only sounds, the noise in the short story "Një pjesë e lindjes.". The character, like in other short stories of Pashku has not any name, any physic description, any status. We cannot do a real identification, we cannot find it in real life, this kind of person. But his condition is the same archetypal status of the Eden Garden, when the human revealed the good and the evil, discover the fear. The story begins with anxious supplicant expression: "Oh God!", that is the metonymy of fear.

The protagonist, is lied in his bed, in quite darkness, and stay all the time with closed eyes, waiting for something that could happen. His point of view is the same as the narration: through the hearing sense, the description is also full of hearing details. The noise of unknown steps, coming in his direction, are scaled in enumeration figure: in the start they are light, noisier, until they are very close to him and the steps are in his bed, invasive and bring him death. "And so. The steps go down from the bed, when now no movement was alive." (Tregime fantastike,1986, p.82). The fear in this story is not physical and selfish. The man has a precious heredity, a carpet from his grand-father, and father, he wants to let this to his son. He takes in his hand all the time a part of the carpet, he is frightened that someone could take that. In Albanian language the word "lindje" (A part of east or A part of birth is the title of story) has two meanings: the first is the direction of horizon and the second is the state of coming in life, the birth of a person. The title of this short story is ambivalent, it means that the fear of protagonist is related with the property, heredity, with the loose of identity. He wants that no unknown step treads in, he feels this like a violation. His carpet stay with him, and this is most important than his life.

In a similar situation the short story "Ora", but a little more concrete. The short story it is developed like a memory of the boy to his father, all their talks, their fights are related to an inherited memory by his father. The clock ticked backward, but it could not be put away or left behind. The dream that his father had showed before he died was : he was in the middle of the mud with his son. The father was surrounded by a lot of youngsters with new watches denoting the right time. The youngsters were teasing his dad. The mud was filled with skeletions. He drops his watch and he dives to catch it , despite the son's asking him to do so. This is the dream that describes the fear of loosing the old time. The watch remains in the house and the son, after his dad's death, buys a new one after realizing that the value of the old watch was not telling the time, but the ancient spirit in it. The watch does not show the physical time, it is a symbol of the surviving on the martirs.

In those stories the fear is scaled through the repetition of the phrases, the fear of the characters until a climax is reached with the closing of the story where the fear continues to be present and ambiguity meaning.

\section{The Terror Grotesque}

The presence of the grotesque in the act of Anton Pashku has been underlined by some critics who have dealt with his act such as, Sabri Hamiti , Rexhep qosja, Alfred Uci etc.

According to Alfred Uci, the characters and the situations are grotesque. He emphasizes that the history of literature has shown that it is easier for the grotesque to be based on comic, funny phenomena. This effect has always been in traditional literature, whereas in the modern literature has accurred a turn in activating irony. What seems serious , dramatic, horrible is submitted to the black irony bitter and at no point funny. This is adoptable to the gloomy , suffocating and disturbing atmosphere. This is particularly observed in : "especially in the stories that show memories and impressions from the time of war, which are coming alive in revealing the contemporan reality , aggressive forces and grotesque instincts. May be the term which would be more suitable to characterizes a series of stories from Anton Pashku is the bitter smile ." (Uçi, Grotesku në historinë e letërsisë dhe estetikë, p.215-216)

In some of short stories with the theme of war, we find the climax, the terror that the character feels through: memory and everyday living. The grotesque element that Anton Pashku has chosen, is the machinery. It is a mechanism which has different shapes, but only one function: the violence of individuality.

Anton Pashku does not give us a panoramic view, his narration is mosaic, constructed with little detail and symbolic images. The short stories create the idea of time and space full of sounds, full of noisy terror , everything has the disgusting taste. The author has also chosen a sense description that makes the reader to take the meaning not only with eyes but with all senses: hearing, smelling, and feeling. The point of view is inside-out, we feel through the mind and spirit of character.

In "Si e përshkroi ëndrrën e vet njeriu me kapele." Short story, the grotesque dream of character is expanded in two times, in war and after war. He has created a building of terror, when people are like dried meat, to be prepared for 
another elaboration. The second process is a room plenty of hungry cats, that are eat everyday human hearts and lungs through some tubes. This terrorized part is seen by the ocular protagonist, who expect to be the next victim. The narration developed through the character memories, that make more dramatic the point of view.

After many years of war, the protagonist saw the same chief of grotesque building, in an important post of policy. The police chief, know is feeding a little crocodile, his animal and carnival instinct has not been changing. That it is actual desire, coming out through black humor.

In "Disa fjalë për një plak dhe librin e tij kushtuar tymit.", the memories of war are transformation and materialized in number and nail, and in a book for smoke. The mechanism of terror here is crematorium, it is not described directly, there are the consequences: the kill off, of whole family in flame and smoke and the emotional death of man. "The factory that vomit smoke", with first material for use: the human bodies.

The crematorium is described with very cold word in "Si e përshkroi ëndrrën e vet njeriu me kapelë" in a dialog between two officers of war that have only a job: to find new kind of death.

In Pashku's short stories, the point of view from victim of violence: is the ocular person, his flashback in the past, his memories for violence. Another point of view is by the person who causes the violence, the war. He is the personification of totalitarian system.

In "Vdekja solemne." We find the point of view of this character. He lives with "black dog", he drinks "black wine", he eats and tastes only "head of animals", and he is very proud for his collection of skulls. The character is realized with black humor. His memories are related with the difficult work of finding the perfect skulls. Through his life he has changed many times this collection and showed it to a lot of colleagues. Only when he takes the best compliments he could finally enjoy his collection. But for the irony of faith, his collection went into flames, he could not support this and committed a suicide together with his dog.

In the short story "Falimentimi i një zotërie" the mechanism for terrifying people is the creation of a movie, who shows the animals in cage coming in direction of the spectators. Mr. Benjamin, when read in a newspaper about this movie, it came out that it was the same idea that he had, someone had stolen his idea. This is the grotesque part: the last scene of the movie should be real, the animal should attack the people, the real cages will be opened to kill the spectator. If this is not achieved, he will be a failed man.

Hamiti has said that, the author has described and detailed the dishumanity action, this is articulated through the irony, black humor and grotesque. The loneliness of human and the victim of human are the consequences of totalitarian system. ( Letërsia bashkëkore shqipe, 2002, p.512)

\section{The Symbolic of Light Against the Darkness}

In the climax of short stories, it is a moment of turn, with two different direction: first is in the stories where the protagonist survives from the memories, believes in the future and has a ray of hope. Second direction it is living life together with the past, sometimes the protagonist past away without any salvation, or live passively their days.

The setting has light color, there dominate the black and white, always depending by the spiritual state of protagonist. Symbolic details, give the reader the meaning of stories. They are symbolic confrontation of light against darkness.

The short stories have no any happy ending or tragic one, but they are a dramatic dichotomy of survival, maybe only with the last common object.

In "Xixëllonjat", the event it is set in a flame war night, it ends before morning. The last sentences presents the fate of the whole life of protagonists: "They never met. She searched for a long time, a very long time, but they never met." This ellipsis of time, shows the triumph of love against the physical death in war.

In "Floçka" it seems that all panorama it is covered with a dark cloth and we cannot see what is hide inside. (Palushi, Në mbretërinë poetike: kritikë për veprën e Anton Pashkut, f.126) The protagonist of this story is searching for Floçka, the beautiful girl of his dream. He went in her living place, but there he find a burning village, plenty of noisy ravens and dogs. The turning point, is the explosion of light from the lake. A part of ravens and dogs were kill off, but not all, some of them are still alive, because a part of evil it is always present.

"Anija e dehur" has an old professor as main character. In his voyage he tried to hide the loneliness through: writing letters for the wife. In reality she has past away in Dachau Camp. The young boy, a co-traveler is impressed by this enigmatic old man that has chosen to live with the idea that no one has died. The peaceful smile, is symbolic victory against the dark memories. Young boy: "...decided to take away that smile." (Pashku, Kulla, 2007, p.48)

In the short stories "Një pjesë e lindjes." and "Ora" the dark ambient where the protagonists lives and dies, have only one solution for continuity, through the symbolic object: the carpet and the clock. 
In "Disa fjalë për një plak dhe librin e tij kushtuar tymit." The protagonist is thrilled by darkness, by smoke. He cannot change anything in his life. He has been emotionally dead a long time ago, together with his family. His pain is materialized in art, to show the others after death that living with dolour is the most difficult thing.

In the most known short story of Pashku, "Kulla", the protagonist in a nightmare memory has a retrospective flashback in history of "Kulla" (tower). The Albanian tower survives after all its confrontation with invaders. The existence of individuality it is related with memory of origin, war, and violence. The existence goes on through light, through liberation of spirit and mind. All this is art of narrating short story, after the author said this: "The darkness is not dense as before." (Kulla, 2007, p.104)

\section{Conclusion}

The short story of Anton Pashku, create a modern narration of theme of war in Albanian literature. He used metonymy, grotesque, symbol, irony and black humor; all together have the same function: create ambivalent meaning.

\section{References}

Berisha, Anton (2002) Në mbretërinë poetike: kritikë letrare për veprën e Anton Pashkut. Shpresa, Prishtinë Einhause, Ann-Marie (2013)The Short Story and the First World War. Cambridge University Press.

Hamiti, Sabri (2002) Letërsia bashkëkohore shqipe. Vepra letrare 10, Faik Konica, Prishtinë

Pashku, Anton (1961) Tregime, Jeta e Re, Prishtinë

Pashku, Anton (1965) Një pjesë e lindjes, Prishtinë

Pashku, Anton (1968) Kulla, Prishtinë

Pashku, Anton (1973) Kjasina, Prishtinë

Pashku, Anton (1978) Lutjet e mbrëmjes, Prishtinë

Pashku, Anton (1998) Tregime fantastike, Prishtinë

Pashku, Anton (1998) Lutjet e mbrwmjes, Rilindja, SHBLSH, Prishtinë

Pashku, Anton (2007) Kulla, Naim Frashëri, Tiranë

Uçi, Alfred (2001) Grotesku në historinë e letërsisë dhe estetikës. Mësëntorja e parë. Tiranë 